\section{In Vitro Propagation of Salicornia bigelovii by Shoot-tip Cultures}

\author{
Chiwon W. Lee ${ }^{1}$ \\ Department of Horticulture, Colorado State University, Fort Collins, \\ CO 80523
}

\author{
Edward P. Glenn ${ }^{2}$ and James W. O'Leary ${ }^{3}$ \\ Environmental Research Laboratory, University of Arizona, Tucson, \\ AZ 85721
}

Additional index words. halophyte, tissue culture, new crop, seed oil crop

Salicornia bigelovii Torr., an annual, succulent species of Chenopodiaceae, has the potential to become one of the first seawaterirrigated crop plants (Glenn et al., 1991). This plant was identified as having the greatest promise among many halophyte species tested for possible domestication as a new oilseed crop (O'Leary, 1988; O'Leary et al., 1985). The objective of this study was to develop a tissue culture medium for clonal propagation of selected plants.

Salicornia seeds were germinated in a greenhouse in 1.8-liter plastic pots containing a mixture of 1 peat : 1 vermiculite : 1 perlite (by volume) and were irrigated with fresh water. Plants were fertilized weekly with a nutrient solution containing $200 \mathrm{ppm} \mathrm{N}$, $88 \mathrm{ppm} \mathrm{P}$, and $166 \mathrm{ppm} \mathrm{K}$. Shoot tips (8 to $10 \mathrm{~mm}$ long) of 2-month-old plants were excised and surface-sterilized for $10 \mathrm{~min}$ in $0.26 \%$ sodium hypochlorite containing $5 \mathrm{mg}$ Tween 20 (surfactant)/liter, followed by four rinses in sterile distilled water. The basal ends of the tips were recut and cultured on a medium containing MS salts (Murashige and Skoog, 1962), B-5 vitamins (Gamborg et al., 1968), and (in mg.liter ${ }^{-1}$ ) 100 inositol, 2 glycine, 30,000 sucrose, and 10,000 Difco Bacto-agar. The combinations of $0.54 \mu \mathrm{M}$ and $10.74 \mu \mathrm{M}$ 1-naphthaleneacetic acid (NAA) and $0.44 \mu \mathrm{M}$ and $8.89 \mu \mathrm{M} \mathrm{N}$-(phenylmethyl)-1 $H$ - purine-6-amine (BA) were used to study their influence on shoot multiplication and root development.

Cultures were grown on $20 \mathrm{ml}$ medium contained in $25 \times 250$-mm glass tubes. Each treatment had 20 replications and the experiment was repeated. All cultures were grown at $21 \pm 2 \mathrm{C}$ under a 30 to $46 \mu \mathrm{mol} \cdot \mathrm{m}^{-2} \cdot \mathrm{s}^{-1}$ light intensity produced by cool-white fluorescent lamps for $16 \mathrm{~h} \cdot \mathrm{day}^{-1}$.

Received for publication 13 May 1991. Accepted for publication 12 Nov. 1991. Funded by the state of Arizona, Electric Power Res. Inst. and Salt River Project. ERL no. 91-21. The cost of publishing this paper was defrayed in part by the payment of page charges. Under postal regulations, this paper therefore must be hereby marked advertisement solely to indicate this fact.

'Associate Professor. Current address: Dept. of Horticulture and Forestry, North Dakota State Univ., Fargo, ND 58105.

${ }^{2}$ Research Scientist.

${ }^{3}$ Professor, Dept. of Molecular and Cellular Biology.
The number of shoots and roots developed on the initial culture varied with the growth regulator concentration. Explants cultured for 8 weeks on a medium containing $0.54 \mu \mathrm{M}$ NAA and $8.89 \mu \mathrm{M}$ BA produced the most shoots per culture (Table 1). The mean length of new shoots was inversely related to the mean number of shoots obtained on the three growth regulator combinations (Table 1). Shoot tips cultured on medium containing $10.74 \mu \mathrm{M}$ NAA and $0.44 \mu \mathrm{M}$ BA initiated an average of 12 roots/explant; cultures did not produce roots on media containing 8.98 $\mu \mathrm{M}$ BA. All growth regulator treatments induced callus formation at the base of the explants; the callus did not interfere with either shoot proliferation or root generation.

Shoots, when divided and subcultured on the MS basal medium supplemented with 0.54 $\mu \mathrm{M}$ NAA and $8.89 \mu \mathrm{M}$ BA, continuously produced 12 to 30 new shoots per culture every 8 weeks (Fig. 1a). The individual shoots elongated and produced healthy roots when transferred to a medium containing $10.74 \mu \mathrm{M}$ NAA and $0.44 \mu \mathrm{M}$ BA (Fig. 1b). The rooted plantlets were transplanted into 0.6-liter plastic pots containing a mixture of 1 peat : 1 vermiculite : 1 perlite. These plants were kept inside a humid polyethylene tent in the greenhouse and acclimatized for 10 days by gradually opening the plastic cover. Most plants survived and grew like seed-grown plants. Our results indicate that mass propagation of salicornia clones from shoot-tip cultures is possible and that this technique may be useful in breeding programs.

\section{Literature Cited}

Gamborg, O.L., R.A. Miller, and K. Ojima. 1968. Nutrient requirements of suspension cultures of soybean root cells. Expt. Cell Res. 50:151-158. Glenn, E.P., J.W. O'Leary, M.C. Watson, T.L. Thompson, and R.O. Kuehl. 1991. Salicornia

Table 1. Shoot multiplication and root formation from Salicomia bigelovii shoot tips cultured in vitro for 8 weeks on media containing NAA and BA.

\begin{tabular}{ccccc}
\hline \hline \multicolumn{2}{c}{$\begin{array}{c}\text { Growth } \\
\text { regulator } \\
(\mu \mathrm{M})\end{array}$} & & \multicolumn{3}{c}{ Shoots } & \\
\cline { 2 - 5 } & & & Length (mm) & Roots (no.)/ \\
NAA & BA & No. \pm SE & culture \pm SE \\
\hline 10.74 & 0.44 & $6.2 \pm 2.2$ & $37.4 \pm 29.0$ & $12.0 \pm 6.5$ \\
10.74 & 8.89 & $16.4 \pm 3.4$ & $16.8 \pm 4.4$ & $0.0 \pm 0.0$ \\
0.54 & 8.89 & $23.0 \pm 8.0$ & $10.8 \pm 4.1$ & $0.0 \pm 0.0$ \\
\hline
\end{tabular}

